people. Mr. Andre Tschiffeli of the ICRC spoke on the importance of dissemination and the necessity of adapting the message to various target groups. The National Societies of Tunisia, North Yemen and Jordan informed the Conference of their intention to organize dissemination seminars.

Finally, the Conference held detailed discussions on the drought in Africa and adopted a resolution in which it thanked international organizations for their relief activites for the drought victims and invited them to take into account in their assistance programmes the protection of the environment.

The next Conference will be held in Mauritania, in 1986, at a date still to be fixed.

\title{
Round Table on the safety of journalists on dangerous professional missions
}

A Round Table was held under ICRC auspices on 23 and 24 April at Mont-Pèlerin sur Vevey (Switzerland) on the theme of the safety of journalists on dangerous professional missions. Sixteen international media organizations -including regional organizations of Africa, Latin America, the Arab world, South-East Asia and North America-had accepted the ICRC's invitation and sent representatives. The Round Table was also attended by numerous correspondents for major press agencies (AFP, Reuter, TASS, Associated Press, etc.), large newspapers with an international readership, and the Swiss Television. The United Nations, UNESCO and the ILO had sent observers.

The purpose of the Round Table was to examine the hazards facing journalists and to consider remedies, including the effectiveness of the legal protection afforded by existing international humanitarian law. Also under appraisal were specific measures already taken or which should be taken to ensure and increase the safety of journalists on dangerous missions.

The ICRC, true to its customary rôle, endeavoured to restrict the debate to the humanitarian aspect of the problem, i.e. to the protection of journalists as human beings victims of treatment and procedures violating the universal humanitarian principles applicable in conflicts and similar situations. 
In the absence of its President, who was on mission in Central America, the ICRC was represented by its Vice-President, Mr. Maurice Aubert, together with Mr. Jacques Moreillon, Director for General Affairs, Mr. Jean-Pierre Hocké, Director for Operational Activities, Mr. Alain Modoux, Head of the Information Department, who organized the Round Table and chaired the discussions, Mr. Hans-Peter Gasser, ICRC legal advisor, and Mrs. Michèle Mercier, Head of the Press Division.

In his opening speech, M. Aubert mentioned that in the past thirty years, some three hundred journalists had been killed while on mission. These facts, he said, "are indicative of a worrisome trend in the state of our world, in which the upsurge of violence has become a global phenomenon". He also stressed the ICRC's growing concern at that trend and its incessant efforts to promote respect for international humanitarian law. "Even though respect for these instruments of law becomes more imperative with each passing day, violations thereof are a daily occurrence. The principles of humanity, which we all agree are inviolable, are forgotten, held up to ridicule. The ICRC is painfully aware of this: how often have its activities been impeded, if not brought to a halt, by what is referred to as 'reason of State'! The situation is paradoxical, for never before has the individual been protected by law to the extent that he is today. The Geneva Conventions and their Additional Protocols alone contain some six hundred articles!"

On behalf of the ICRC, Mr. Aubert expressed the institution's gratitude for the support it received from journalists. The ICRC "never forgets that information is the most effective support weapon. For it is by your work in sensitizing the public that you help the humanitarian cause".

He gave a summary of the evolution of the main instruments of international humanitarian law, which embody so many attempts to limit the suffering caused by conflicts, and in particular pointed out that Art. 79 of the 1977 Protocol I stipulated that "Journalists engaged in dangerous professional missions in areas of armed conflict shall be considered as civilians..." and that consequently, international humanitarian law afforded them the same protection as that to which civilians were entitled.

$\mathrm{He}$ also mentioned the situations of internal tension and disturbances in which these instruments are not applicable and which are often a pretext for the worst of deeds. "Among the victims are journalists, embarrassing witnesses to be neutralized, if not done away with altogether", Mr. Aubert said. 
He added, "You have an important job-the job of informing the public about what is happening in the world-and I believe that you do it perfectly aware of the risks, with the knowledge that there are dangerous missions,... dangers inherent in any war. However, what you do not accept, because they are unacceptable, are the deliberate acts - arrest, prolonged detention, ill-treatment, abduction, murder-designed, in disregard of your freedom or even your life, to keep you from doing your job. These risks are not part of the "normal course of events'."

At the close of the two-day meeting, the representatives of the media, while aware of the ICRC's difficulties in carrying out its traditional mandate, put forward the request that it should reinforce its protection and assistance activities on behalf of journalists on dangerous missions, especially in the event of capture, disappearance or detention. They also recommended that a kind of "hot line" be installed at ICRC headquarters in Geneva, whereby professional associations and editors could contact the ICRC 24 hours a day to alert it to any emergency situation requiring immediate action on behalf of a journalist in peril. They also encouraged the ICRC to organize regional seminars for the promotion of knowledge and understanding, among journalists, of the scope and restrictions of its activities and of the essential provisions of international humanitarian law.

Finally, the representatives of the sixteen organizations participating in the Round Table told the ICRC that they had total confidence in the manner it would follow up the suggestions made and, so as to avoid lapsing into the essentially political controversies which had marred previous meetings held under auspices other than those of the ICRC, they concurred that they would let it be the judge of the course it deemed most appropriate to pursue the dialogue which had now been initiated. 